\title{
Model Revitalisasi Pasar Tradisional Terapung Untuk Menunjang Logistik Wilayah Pedalaman: Studi Kasus Sungai Barito
}

\author{
Chandra Karta Yudha, Tri Achmadi, Siti Dwi Lazuardi \\ Departemen Teknik Transportasi Laut, Fakultas Teknologi Kelautan, \\ Institut Teknologi Sepuluh Nopember (ITS) \\ e-mail:dwilaz@seatrans.its.ac.id
}

\begin{abstract}
Abstrak-Banjarmasin merupakan wilayah yang memiliki 103 sungai yang salah satunya digunakan untuk pasar terapung. Tetapi kondisi Pasar Terapung tidak seramai dahulu, seiring dengan berkembangnya zaman keberadaan pasar terapung ini mulai mengalami penurunan, baik dari sisi luas kawasan, jumlah penjual, jumlah transaksi jual beli dan lain-lain. Sementara itu Undang-undang nomor 7 tahun 2014 tentang Perdagangan, pasal 13 ayat (1), (2) dan (3) yang mengamanatkan bahwa Pemerintah bekerja sama dengan Pemerintah Daerah melakukan pembangunan, pemberdayaan, dan peningkatan kualitas pengelolaan pasar rakyat guna peningkatkan daya saing. Tujuan dari penelitian membuat model revitalisasi pasar apung dengan memperbaiki fasilitas kapal dan dermaga. Metode yang digunakan dalam penentuan ukuran utama dan jumlah kapal adalah optimasi. Dan hasil dari penelitian diperoleh revitalisasi kapal menggunakan material kayu ukuran panjang (Lpp) 11,97 m, lebar (B) 3,05 m, tinggi (H) 2,4 dan sarat (T) 1,7 m dengan tarif Rp. 70.000,-/ton. Sementara itu pengadaan dermaga dengan ukuran panjang $58 \mathrm{~m}$, lebar 10 $m$ dan tinggi 8,8 m membutuhkan investasi sebesar 1,6 miliar rupiah dengan jenis dermaga terbuat dari kubus HDPE. Dengan adanya revitalisasi tersebut mengakibatkan kenaikan biaya angkut kapal sebesar $40 \%$ sehingga diperlukan subsidi dari pemerintah untuk menutupi kenaikan biaya tersebut sebesar 20 ribu rupiah/ton.
\end{abstract}

Kata Kunci-Pasar Apung, Revitalisasi, Investasi.

\section{PENDAHULUAN}

$\mathrm{B}$ ANJARMASIN adalah wilayah dengan jumlah sungai se-banyak 103 buah, salah satunya digunakan untuk pasar terapung. Tetapi kondisi Pasar Terapung tidak.seramai dahulu, seiring dengan berkembangnya zaman pasar terapung ini mulai mengalami penurunan, baik dari sisi luas kawasan, jumlah penjual, transaksijual beli dan lain-lain. Sementara itu Banjarmasin merupakan kota terpadat pertama yang berada di Provinsi Kalimantan Selatan. Jumlah penduduk di Banjarmasi pada tahun 2016 mencapai 684.183 jiwa, dengan angka pertumbuhan penduduk rata rata sebesar 2,42\% setiap tahun [1]. Selain itu perekonomian Kota Banjarmasin juga mengalami pertumbuhan setiap tahunnya. Pada tahun 2016 pertumbuhan ekonomi Kota Banjarmasin meningkat sebesar 6,28\% dibanding tahun sebelumnya dengan pertumbuhan ekonomi sebesar 5,79\% [1].

Dari kondisi penduduk dan ekonomi masyarakat Kota Banjarmasin yang meningkat dan permasalah penurunan aktivitas pasar apung maka diperlukan perbaikan atau revitalisasi pasar apung yang berada di wilayah aliran sungai barito, yang berguna untuk menunjang perdagangan logistik di sekitar aliran Sungai Barito. Selain alasan di atas, program revitalisasi pasar juga didukung oleh Undang-undang nomor 7 tahun 2014 tentang Perdagangan, pasal 13 ayat (1), (2) dan (3) yang mengamanatkan bahwa Pemerintah bekerja sama dengan Pemerintah Daerah melakukan pembangunan, pemberdayaan, dan peningkatan kualitas pengelolaan pasar rakyat guna peningkatkan daya saing. Dalam penelitian ini akan dilakukan kajian terhadap permintaan barang konsumsi di kawasan aliran Sungai Barito dan untuk menilai kelayakan investasiuntuk revitalisasi pasarapung.

\section{METODOLOGI PENELITIAN}

\section{A. Metode Pengumpulan Data}

Pada tahap ini dilakukan pengumpulan data, metode pengumpulan data yang digunakan adalah metode pengumpulan data secara tidak langsung (sekunder) dan data primer yang didapatkan dari hasil kuesioner dan pengamatan langsung. Pengumpulan data ini dilakukan dengan mengambil data terkait dengan permasalahan dalam penelitian ini ke Pasar Apung Muara Kuin Banjarmasin. Data primer meliputi jumlah perahu, kapasitas angkut perahu, dan sistem operasi pasar apung. Sedangkan untuk data sekunder meliputi PDRB dan tingkat konsumsi atas barang perkapita penduduk Banjarmasin.

\section{B. Metode Pengerjaan Penelitian}

1. Tahap Identifikasi Masalah

Pada tahap ini dilakukan identifikasi permasalahan tugas akhir yang berhubungan dengan revitalisasi pasar tradisional apung di wilayah Sungai Barito. Beberapa hal yang menjadi fokusan identifikasi merupakan masalah penawaran, permintan, fasilitas dan sistem operasional.

\section{Tahap Analisis}

Pada tahap ini data yang telah dikumpulkan dari hasil studi lapangan yang diolah lebih lanjut sehingga dapat digunakan sebagai perhitungan untuk perhitungan penawaran dan permintaan, investasidan biaya logistik. Pengolahan data bertujuan untuk mencari perbandingan biaya logistik sebelum dan sesudah revitalisasipasar apung.

Konsep revitalisasi yang ditawarkan dalam penelitian ini memberikan 3 alternatif dalam pengadaan kapal yaitu kapal baja, kayu dan fiber. Dimana dari alternatif tersebut akan dipilih kapal yang menghasilkan biaya paling murah, sehingga tarif angkutnya tidak akan terlalu mahal. Sementara itu alternatif yang diberikan dalam pengadaan dermaga yaitu dermaga dari material beton dan floaton (HDPE). 


\section{Metode Perhitungan}

Model perhitungan dijelaskan tentang model matematis dari pengerjaan penelitian ini dengan metode yang digunakan adalah optimasi. Dimana objectif function atau tujuan dari model optimasinya adalah unit cost. Dengan decision variable adalah ukuran utama kapal (LPP, B, H dan T). Berikut ini adalah persamaan dari model matematis untuk penentuan ukuran utama kapal dengan minimum unit cost :

$$
\begin{gathered}
\operatorname{Min} Z=\sum_{i=1}^{3} \frac{T C_{i}}{Q_{i}} X_{i} \\
\operatorname{Min} Z=\frac{T C_{1}}{Q_{1}} X_{1}+\frac{T C_{2}}{Q_{2}} X_{2}+\frac{T C_{3}}{Q_{3}} X_{3}
\end{gathered}
$$

Keterangan :

$$
\begin{array}{ll}
\mathrm{Z} & =\text { Unit Cost } \\
\mathrm{TC} & =\text { Total Cost } \\
\mathrm{Q} & =\text { Produksi (Total Muatan Diangkut) } \\
1,2,3 & =\text { Alternatif material kapal } \\
\mathrm{X} & =\text { Bilangan Biner ( } 1 \text { jika alternatif terpilih, } 0 \text { jika }
\end{array}
$$$$
\text { alternatif tidak terpilih ) }
$$

Dimana :

Keterangan :

$$
\operatorname{Min} Z=\frac{n_{i} \cdot F C_{i}+n_{i} \cdot f \cdot V C_{i}}{n_{i} \cdot f_{i} \cdot P i_{1}} X_{i}
$$

$$
\begin{array}{ll}
\mathrm{FC} & =\text { Fix Cost } \\
\mathrm{VC} & =\text { Variabel Cost } \\
\mathrm{n} & =\text { Jumlah Kapal } \\
\mathrm{f} & =\text { Frekuensi } \\
\mathrm{Pi} & =\text { Payload }
\end{array}
$$

Batasan :

$n_{i} . f_{i .} . P i_{i} \geq$ Demand (146 ton)

$\mathrm{Pi}_{1}, \mathrm{Pi}_{2}, \mathrm{Pi}_{3} \leq$ Payload maksimum ( 20 ton )

$F r_{1}, F r_{2}, F r_{2} \geq$ Freeboard minimum $(0,75 \mathrm{~m})$

\section{III.GAMBARAN UMUM}

\section{A. Lokasi Pasar Apung}

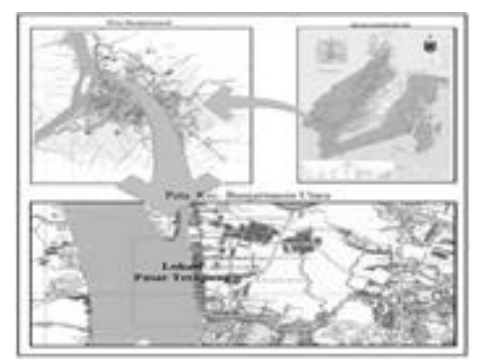

Gambar 1. Lokasi Pasar Apung.

Secara administratif Pasar Terapung masuk ke dalam wilayah Kecamatan Banjar Utara. Tepatnya pasar ini berada di Kelurahan Kuin Utara. Letaknya cukup strategis dengan panorama alam yang indah, khususnya di pagi hari, dan ditunjang dengan beberapa obyek wisata tirta lainnya. Pasar ini mulai terlihat aktivitasnya mulai subuh (jam 4) hingga jam 8 pagi. Sampai saat ini terdapat \pm 200 perahu yang ada di kawasan pasar terapung dan didominasi oleh perahu-perahu tradisional (jukung) dan sisanya perahu dengan menggunakan mesin atau sering disebut klotok.

\section{B. Fasilitas Pasar Apung}

Tabel 1.

Fasilitas Pasar Apung

\begin{tabular}{llc}
\hline \hline \multicolumn{1}{c}{ Jenis Fasilitas } & \multicolumn{1}{c}{ Fungsi } & $\begin{array}{c}\text { Jumlah } \\
\text { (Unit) }\end{array}$ \\
\hline Perahu Klotok Barang & $\begin{array}{l}\text { Pedagang Besar (Pengangkut } \\
\text { Barang) }\end{array}$ & 20 \\
Perahu Jukung & Pengecer (Pengangkut Barang) & 150 \\
Perahu Klotok & Pengangkut Pengunjung & 10 \\
Penumpang & Penjual Makanan & 20 \\
Perahu Klotok & Sandar Kapal & - \\
Dermaga &
\end{tabular}

Sumber : Dinas Pariwisata dan Kebudayaan Banjarmasin

Perahu yang digunakan oleh masyarakat untuk menjual dagangannya mayoritas menggunakan perahu jukung dan sisanya perahu semi-klotok, sedangkan perahu yang digunakan untuk menjual kuliner dan wisata adalah perahu klotok mesin. Untuk fasilitas dermaga pada saat ini masih belum ada,jadi kapal kapal yang berada di pasarapung hanya berlabuh.

Jukung yaitu perahu kecil yang berukuran panjang 3-4 meter dan lebar 1 meter. Perahu ini digerakkan dengan menggunakan dayung. Perbedaan klotok dan jukung adalah klotok sudah digerakakan dengan tenaga mes in diesel.

\section{Proses Bisnis}

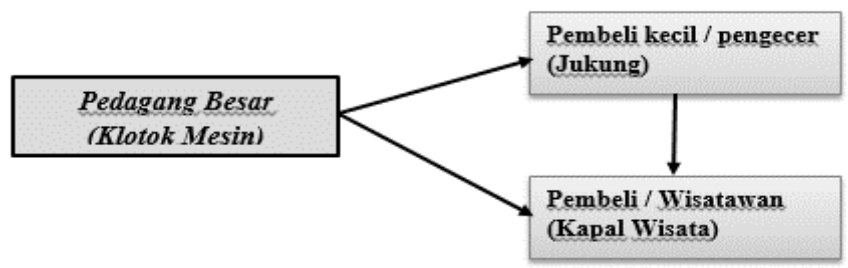

Gambar 2. Proses Bisnis Pasar Apung.

Pada umumnya para pedagang yang berjualan di Pasar Apung menjual barang dagangan dalam partai besar disebut sebagai pedagang besar, sementara sebagian yang menjual dalam partai kecil disebut pedagang kecil. Pedagang kecil tersebut akan berlaku sebagaipengecer dan menjual kembali kepada masyarakat di sekitar pasar yang ada di darat, atau memasarkannya disepanjang sungai yang dilewati. Dan dijajakan kepada wisatawan yang berkunjung ke Pasar Apung.

\section{ANALISIS PEMBAHASAN}

A. Hasil Survei

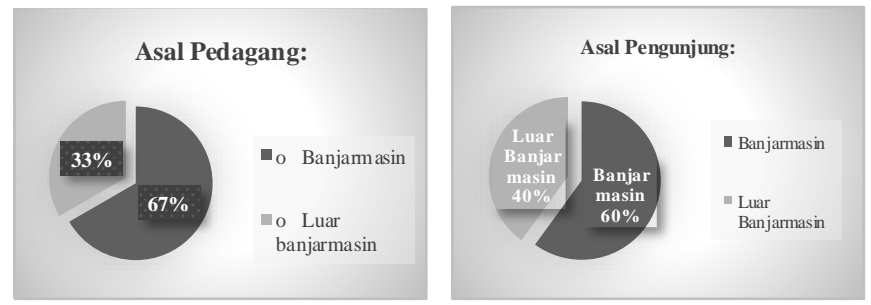

Gambar 3. Asal Pedagang dan Pengunjung.

Jumlah responden yand diambil adalah sebanyak 30 orang, baik itu Pedagang maupun Pengunjung. Untuk Pedagang prosentasenya 33\% dari Banjarmas in dan 67\% dari luar Banjarmasin. Sementara Pengunjung 60\% dari Banjarmasin dan 40\% dari Luar Banjarmasin. 
Tabel 2.

Penilaian Fasilitas Pasar Apung

\begin{tabular}{|c|c|c|c|}
\hline Kondisi Saat Ini & Nilai & $\begin{array}{l}\text { Skala } \\
\text { Linkert }\end{array}$ & t Kondisi \\
\hline Fasilitas sandar kapal sudah baik & 45 & $30 \%$ & Buruk \\
\hline $\begin{array}{l}\text { Kondisi kapal kapal di pasar apung sudah baik } \\
\text { untuk proses jual beli }\end{array}$ & 72,5 & $48 \%$ & Cukup \\
\hline Penataan kapal di pasar apung sudah baik & 70 & $47 \%$ & Cukup \\
\hline
\end{tabular}

Jawaban dari kuesioner dalam evaluasi kondisi pasar apung akan dinilai dengan menggunakan metode skala linkert. Evaluasi kondisi pasar apung meliputi kondisi fasilitas sandar kapal dan kondisi kapal. Sehingga dari hasil survei diperoleh kesimpulan fasilitas yang perlu direvitalisasi adalah Kapal Besar dan Dermaga.

\section{B. Analisis Permintaan}

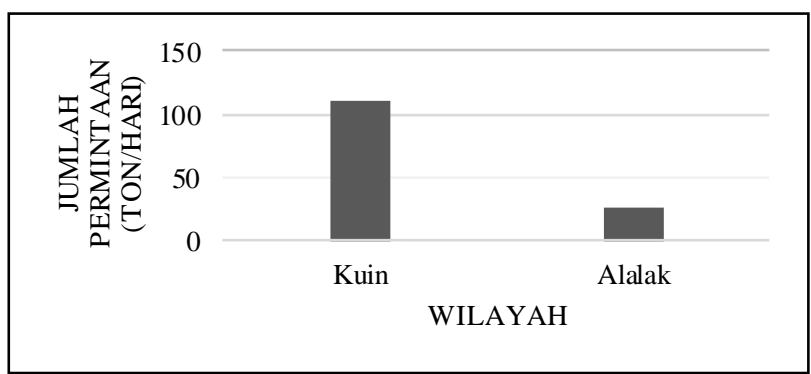

Gambar 4. Permintaan Barang.

Jumlah permintaan kemudian diperoleh dengan data jumlah penduduk yang telah dimiliki dikalikan dengan tingkat konsumsi atau pemakaian barangnya perkapita. Dan diperoleh permintaan barang yang harus disuplai oleh pasar apung dalam satu hari adalah 138 ton.

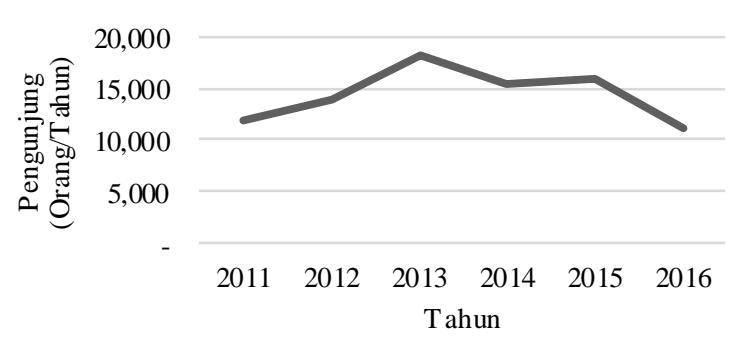

Gambar 5. Tren Pengunjung.

Data jumlah wisatawan pada tahun 2016 dengan total paling banyak per hari adalah 181 wisatawan. Untuk menentukan jumlah pengunjung kapal pasar apung yang akan didesain maka dari data terbanyak 181 wisatawan diambil Jumlah wisatawan per hari sebanyak 20 orang/kapal

\section{Operasi Pasar Apung}

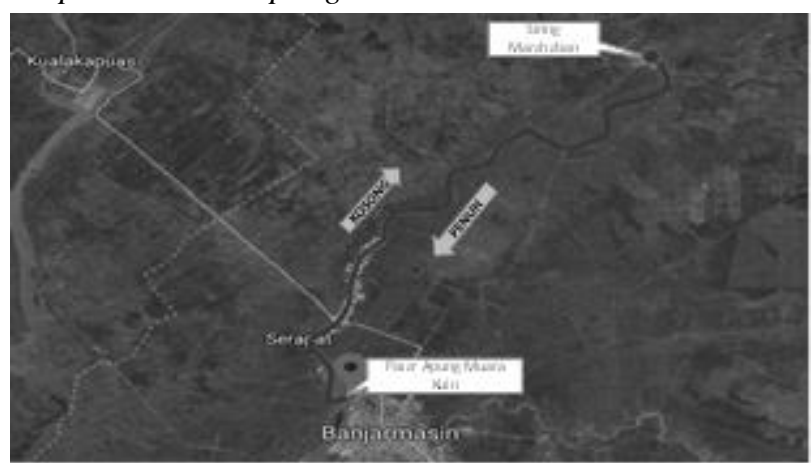

Gambar 6 Rute Kapal.

Rute yang dilalui oleh kapal (klotok) adalah menyusuri perairan Sungai Barito dimulai dari Marahaban sebagai asal pedagang besar sampai kawasan Pasar Apung Muara Kuin sebagai tujuan pedagang besar untuk berjualan. Jarak yang harus ditempuh oleh kapal (klotok) yaitu sejauh 32,4 Nm, dengan kecepatan saat ini 4 knot sedangkan untuk kecepatan ketika direvitalisasi adalah 6 knot. Kondisi muatan ketika berangkat dari Marahaban adalah penuh dan ketika kembali kondisi muatan kosong. Komoditi yang diangkut adalah buah, sayurdan hasil panen

Tabel 3

Waktu Kerja Pasar

\begin{tabular}{|c|c|c|c|c|c|c|c|}
\hline \multirow[b]{2}{*}{$\begin{array}{c}\text { Kondis } \\
\text { i }\end{array}$} & \multirow[b]{2}{*}{$\begin{array}{c}\text { Jarak } \\
\mathrm{Nm}\end{array}$} & \multirow[b]{2}{*}{$\begin{array}{c}\text { Seatim } \\
\text { e } \\
\text { (jam) }\end{array}$} & \multicolumn{2}{|c|}{ Port Time } & \multirow[b]{2}{*}{$\begin{array}{l}\text { Total } \\
\text { Time } \\
\text { (jam) }\end{array}$} & \multirow[b]{2}{*}{$\begin{array}{c}\text { Jam } \\
\text { Buka } \\
\text { Pasa } \\
\text { r }\end{array}$} & \multirow{2}{*}{$\begin{array}{c}\text { Jam } \\
\text { Tutu } \\
\mathrm{p} \\
\text { Pasa } \\
\mathrm{r}\end{array}$} \\
\hline & & & $\begin{array}{l}\text { Asal } \\
\text { (jam) }\end{array}$ & $\begin{array}{l}\text { Tuju } \\
\text { an } \\
\text { (jam) }\end{array}$ & & & \\
\hline $\begin{array}{l}\text { Kondis } \\
\text { i Saat } \\
\text { ini }\end{array}$ & 32,4 & 16 & 4 & 4 & 24 & $\begin{array}{l}4.00 \\
\mathrm{AM}\end{array}$ & $\begin{array}{r}8.00 \\
\text { AM }\end{array}$ \\
\hline $\begin{array}{c}\text { Revital } \\
\text { isasi }\end{array}$ & 32,4 & 10 & 4 & 10 & 24 & $\begin{array}{l}4.00 \\
\text { AM }\end{array}$ & $\begin{array}{l}2.00 \\
\text { PM }\end{array}$ \\
\hline
\end{tabular}

Pada tabeldiatas diperoleh total waktu kerja kapal sebesar 10 jam dengan total sea time sebesar 10 jam dan port time sebesar 6 jam, waktu kapal tidak bekerja sebesar 8 jam. Dari hasil penjadwalan kapal diperoleh kapal harus berangkat dari Marahaban pada pukul 10.36 malam sehingga bisa sampai di pasar apung pada 04.00 pagi. Sementara kapal akan sampai di Marahaban kembali pada pukul 6.37 sore. Karena waktu tempuh berkurang pada saat direvitalisasi jam buka dari pasar apung sendiri akan bertambah dari yang semula hanya buka 4 jam dari jam 4 pagi sampai 8 pagi akan menjadi lebih lama yaitu sampai jam 2 siang. Sehingga kapal akan kempali ke tempat asaljam 2 siang dan sampai Marahaban jam 6.37 sore.

\section{Hasil}

\section{Kapal}

Metode yang digunakan dalam penentuan ukuran utama kapal adalah optimasi dengan tujuan biaya paling minimal. Dalam perencanaan revitalisasi kapal terdapat 3 alternatif yaitu kapalyang terbuat dari bahan baja, kayu dan fiber. Hasilnya kapal yang terpilih adalah kapal kayu berjumlah 8 unit dengan ukuran utama LPP sebesar $11,97 \mathrm{~m}$, B sebesar 3,05 m, H sebesar 2,43 m dan T sebesar 1,68 m.

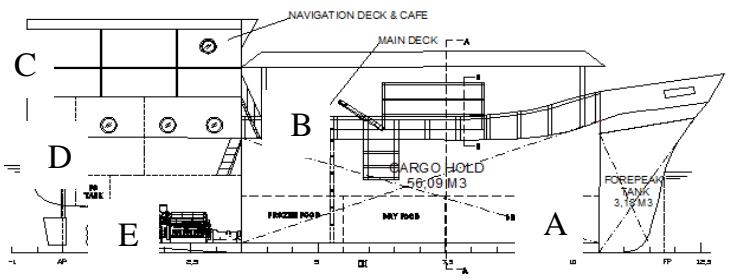

Gambar 7 Tampak Samping Kapal

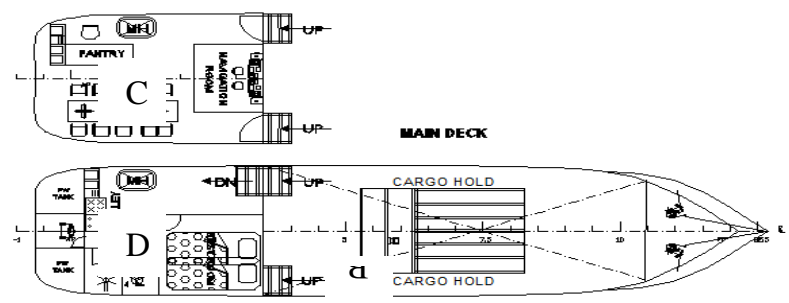

Gambar 8 Tampak Atas Kapal

Adapun ruangan utama dimaksud dalam revitalisasi kapal besar adalah : A.Ruang Muat, B.Geladak Utama (Tempat Berjualan Barang), C.Cafe dan Ruang Navigasi, 
D.Ruang Awak, E.Ruang Mesin dan Tangki-tangki. Dengan rincian Biaya :

1. Biaya Pembangunan Kapal : Rp. 369.009.664

2. Biaya Operasional Kapal : Rp. 298.176.024,-/tahun

3. Biaya Pelayaran Kapal : Rp. 184.694.369,-/tahun

Dan unit cost yang didapat adalah Rp. 70.000,-/ton, naik $40 \%$ dari unit cost saat ini sebesar 50.000,-/ton.

\section{Dermaga}

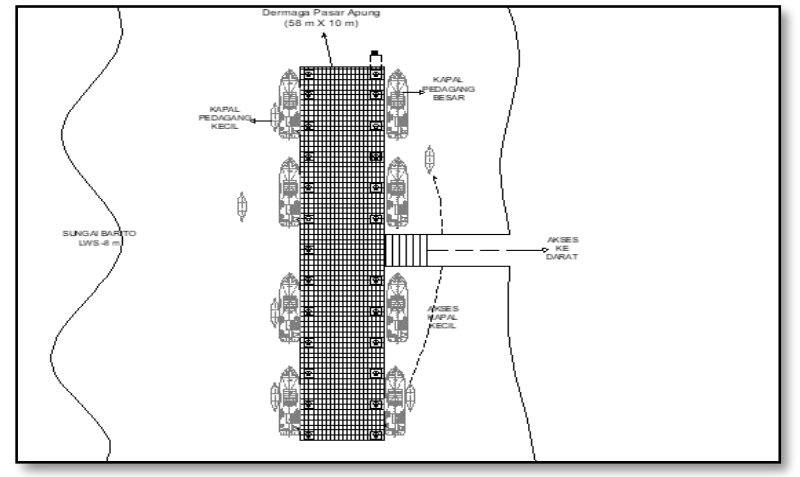

Gambar 9 Tamapak Atas Dermaga Pasar Apung.

Panjang dermaga total untuk semua kapal $58 \mathrm{~m}$ dengan 2 sisi tambatan, lebar dermaga $10 \mathrm{~m}$ dan tinggi $8,8 \mathrm{~m}$. Pengadaan dermaga pasar apung terdapat 2 alternatif yaitu dermaga terbuata dari beton dan kubus HDPE. Dengan jenis material yang terpilih adalah kubus HDPE. Dan biaya pembangunan dermaga sebesar 2,6 miliar rupiah.

Sementara itu untuk proses operasi ketika terdapat pengadaan dermaga pasar apung akses menuju pasar apung bisa diakses melalui darat maupun sungai. Akses melalui darat bisa dilakukan melalui dermaga dan akses dari sungai bisa dilakukan melalui kapal. Sehingga mempermudah akses menuju pasar. Detail proses operasi pasardapat dilihat dalam gambar tampak samping dermaga berikut ini :

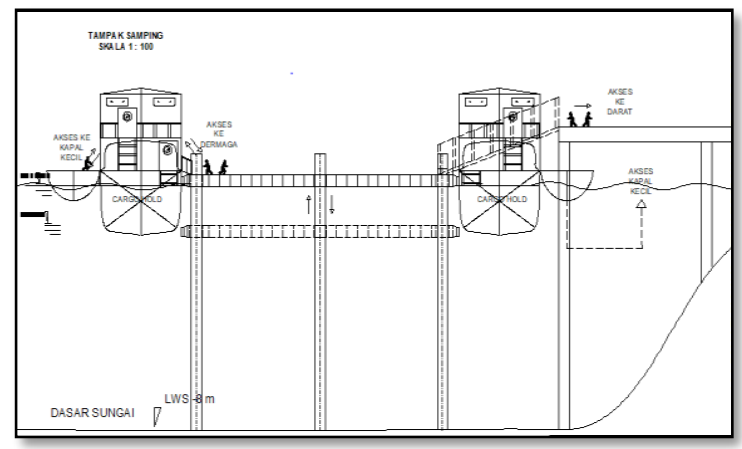

Gambar 10 Tampak Samping Dermaga

\section{Investasi}

Perhitungan dari analisis investasi terdiri dari 2 skenario yaitu subsidikenaikan tarif (skenario 1) atau subsidi untuk pengadaan kapal (skenario 2). Hasil perhitungan analisis investasi sebagai berikut :

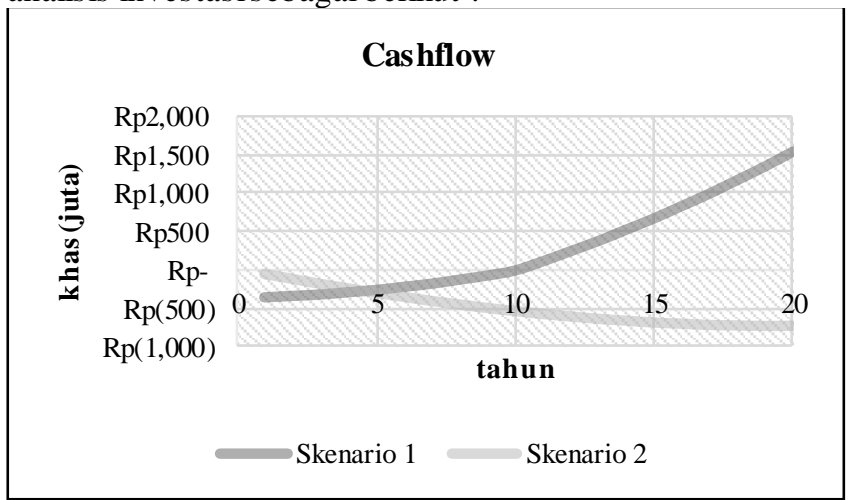

Gambar 11 Arus Khas

Arus khas akan mencapai BEP pada tahun ke 11 adalah skenario 1, dengan subsidi sebesar 135 juta rupiah/tahun. Pendapatan lain adalah dari kunjungan cafe dengan pendapatan bersih 5,5 juta/bulan dengan kunjungan wisatawan 20 orang/hari. Jadi yang terpilih adalah skenario 1.

\section{KESIMPULAN/RINGKASAN}

Berdasarkan hasil perhitungan dan analisis, dapat disimpulakan sebagai berikut :

1. Dari hasil optimasi ukuran utama kapal diperoleh hasil yaitu :

$\mathrm{LPP}=11,97 \mathrm{~m}, \mathrm{~B}=3,05 \mathrm{~m}, \mathrm{H}=2,18 \mathrm{~m}, \mathrm{~T}=1,68 \mathrm{~m}$ dan jumlah kapal $=8$ unit

2. Alternatif material kapal yang terpilih adalah kapal kayu, dengan hasil unit cost termurah sebesar Rp. 70.000,-/ton .

3. Penentuan ukuran dermaga berdasarkan kebutuhan tambatan kapal diperoleh ukuran utama dermaga yaitu : Panjang $=58 \mathrm{~m}$, Lebar $=10 \mathrm{~m}$ dan Tinggi $=8,8 \mathrm{~m}$

4. Alternatif yang terpilih untuk pengadaan dermaga adalah dermaga apung HDPE, dengan investasi sebesar Rp 2.663.085.427.

5. Dari hasil perhitungan model revitalisai pasar apung maka akan mempengaruhi kenaikan biaya pengiriman sebesar $40 \%$.

6. Besarnya subsidiyang harus dikeluarkan oleh pemerintah untuk menutupi kenaikan biaya sebesar Rp 20.000,-/ton, dalam satu tahun sebesar Rp135.357.456.

\section{UCAPAN TERIMA KASIH}

Penulis mengucapkan terima kasih kepada Dinas Pariwisata dan Kebudayaan Banjarmasin serta Pedagang dan Pengunjung Pasar apung yang menjadi responden penelitian ini.

\section{DAFTAR PUSTAKA}

[1] BPS, “Banjarmasi Dalam Angka,”Banjarmasin, 2017. 